\title{
Chapter 10 Overwiev of general plant toxicology uses and adverse effects
}

Capítulo 10 Generalidades de la toxicología forense usos y efectos adversos de las plantas

GONZÁLEZ-GARCÍA, Arcelia’, HERNÁNDEZ-SALAS, Claudia', MARTÍNEZ-ORTIZ, Rosa María" and GONZÁLEZ-MARTÍNEZ, Lilia'

'Universidad Autónoma de Zacatecas, Academic Unit of Chemical Sciences, Mexico.

"Universidad Autónoma de Zacatecas, Academic Unit of Dentistry, Mexico.

ID $1^{\text {st }}$ Author: Arcelia, González-García / ORC ID: 0000-0003-0674-1072

ID $1^{\text {st }}$ Co-author: Claudia, Hernández-Salas / ORC ID: 0000-0001-7492-1310)

ID $2^{\text {nd }}$ Co-author: Rosa María, Martínez-Ortiz / ORC ID: 0000-0001-7811-169X)

ID $3^{\text {rd }}$ Co-author: Lilia, González-Martínez / ORC ID: 0000-0002-3679-0070)

DOI: $10.35429 /$ H.2021.13.113.130

A. González, C. Hernández, R. Martínez and L. González

* Arcelia.gonzalez@uaz.edu.mx

A. Marroquín, J. Olivares, M. Cruz, L. Cruz. (Coord.) CIERMMI Women in Science TXIII Medicine and Health Sciences. Handbooks-@ECORFAN-México, Querétaro, 2021. 


\begin{abstract}
That is why this work aims to know the generalities and the toxic substances include those of the organic and inorganic type. Hence, those of the organic type can be ethanol, most of the medicines and poisons of both animal and vegetable and pharmacological origin. Regarding inorganics, we can consider heavy metals, as well as caustic toxins such as sodium hydroxide. Chemical exposure today in the social environment can be very aggressive in extremely low doses. Speaking of any chemical it can be toxic if it is consumed, ingested or absorbed in excess. This can be through food, water, air, or other sources. Therefore, individuals can respond to toxic chemicals in different ways since some are often more sensitive to a specific chemical and can be excessively dangerous. Toxicological effect when supplying plants such as castor, caper flower and giant in male wistar spraley rats.
\end{abstract}

\title{
Toxicology, Uses of plants, Adverse effects
}

\section{Resumen}

Dentro de las sustancias tóxicas se incluyen las del tipo orgánico e inorgánico. De ahí que las del tipo orgánico pueden ser el etanol, la mayor parte de los medicamentos y venenos tanto de origen animal como vegetales y farmacológicos. Respecto de los inorgánicos, podemos considerar los metales pesados, así como también los tóxicos cáusticos como el hidróxido de sodio. La exposición de los químicos hoy en día en el entorno social puede ser muy agresiva en dosis extremadamente bajas. Hablando de cualquier químico puede ser toxico si es consumido, ingerido o se absorbe en exceso. Ésta puede ser a través de la comida, agua, aire u otras fuentes. Por ende, los individuos pueden responder a los químicos tóxicos de diferentes maneras puesto que algunos suelen ser más sensibles a un químico especifico pudiendo ser excesivamente peligrosos. Es por ello que en este trabajo se pretende conocer las generalidades y el efecto toxicológico al suministrar plantas como son la higuerilla, flor de alcaparra y gigante en ratas wistar spraley macho.

\section{Toxicología, Usos de plantas, Efectos adversos}

\subsection{Introduction}

Nowadays the body responds when exposed to toxic substances, so it is important to ask ourselves what is toxic exposure and what is toxicology?

Toxicology is defined as "The science that deals with the study of poisons (toxins) and their effects", as Paracelsus says everything in excess is poison according to the dose. A poison "is more restrictive and should be reserved for substances that in any dose are harmful to the living organism; furthermore, any substance is toxic when it causes harmful health and/or lethal effects in very small doses either by "iatrogenic" poisoning, accidental suicide or in a planned manner when administered to a living organism" (Hodgson and Smart, 2008; Penningroth, 2010). The origins are remote, according to the Ebers Papyrus (1500) BC toxicology deals with the study of the adverse effects of xenobiotics (from the Greek, "xeno" (foreign) biotic (life) meaning compound foreign to life) of chemical agents that damage the organism.

Such a definition suggests that toxicology is an applied science; therefore, its study has a direct impact on society. In the words of "Gallo \& Dull": as medicine toxicology is both science and art, so that the role of the toxicologist is important in everyday life.

Today the toxicologist's involvement in different disciplinary areas of work ranges from environmental protection to the production of safe medicines with minimal side effects, the field of action in general is wide. He can be involved in the study of the toxic effects of chemical agents on man, in forensic science, the investigation of the role of chemical toxicants in the "safe" drug industry, agrochemicals, toxicants in legal cases as is the case in forensic toxicology whose main function is to identify, study and describe the doses, nature, incidence, severity, reversibility and mechanisms of toxic effects. In addition, it can also intervene in another area such as ecotoxicology which refers to toxic effects of chemical compounds in ecosystems and regulation of chemicals that are toxic, as well as the potential effects of toxic chemical agents in "everyday use" (Hodgson et al., 1998). 
It is also important to mention that toxicology as well as biochemistry, medicinal chemistry, pharmacology and applied biology are directly related to medicine for clinical diagnosis, treatment of poisoning and toxic effects of drugs, insecticides, herbicides, fungicides, etc., as high doses have a harmful impact on the organism and side effects are of great significance nowadays. Molecular biology, pharmacology, chemistry and forensic medicine are fundamental to toxicology, so much so that the progress of toxicology is directly related to the development of new methods in these sciences.

Thus, one of the branches of toxicology that is relevant to this research is forensic toxicology. In forensic toxicology, chemistry provides analytical methods for the study of toxicants and their metabolites, residue analysis and metabolism of toxicants. Biochemistry provides methods for the investigation of the metabolism and mechanism of action of toxicants, while molecular genetic biology, pharmacology and forensic medicine contribute methods for the investigation of the role of genes and gene expression in toxicity (Hodgson and Smart, 2008).

Hence, toxicants can be classified by their origin, physical state, target organ, chemical composition and mechanism of action. First, a toxicant is any physical radiation or chemical agent that, when in contact with a foreign agent or when absorbed by a living organism, can produce a direct or indirect adverse effect on it (Guitart, 2008).

In terms of their origin, they can be mineral, botanical or synthetic. By their physical state: liquid toxicants, dusty toxic solids, gaseous toxicants and volatile toxicants. As far as white organ solvents are concerned, there are hepatotoxic and nephrotoxic solvents. Then, according to their chemical composition, there are aromatic amines and halogenated hydrocarbons, and according to their mechanism of action, there are sulphhydryl inhibitors, cholinesterase inhibitors and metahaemoglobinaemia.

On the other hand, caustic poisons are those that cause destructive alterations by direct action on the skin and mucous membranes. Some are used for domestic use in sanitary cleaners and drains. Hence, the main ones are strong acids and alkalis. Therefore, acids include sulphuric acid, hydrochloric acid, nitric acid, oxalic acid, acetic acid, etc. With regard to alkalis, potassium hydroxide, sodium carbonate, etc. stand out.

In addition, within toxicology it is also important to mention biomarkers. There are three types: biomarkers of exposure of the organism to the toxic substance, biomarkers of the organism's response to the exposure, biomarkers of the organism's susceptibility to the chemical. These effects are properly included in toxicology, whereas endogenous generation of high levels of metabolic intermediates due to diseases or metabolic defects are not, and the effects on the organism may be similar (Smarth and Hodgson, 2008).

After mentioning the generalities of toxicology, another element to consider is toxic exposure. When one comes into contact with a toxicant one is said to be exposed to the chemical. In this regard, acute toxicity is often investigated in experimental animals such as rats. They are exposed to a toxic substance which is a chemical that can injure or kill a person, animal or plant: it is a poison. So the toxic effect is a fatal parameter, death.

Plants are known to be fundamental in the development of modern medicine. They are also essential to life by producing oxygen, regulating the water cycle and being the basis of food chains, nutrients, vitamins and industrial raw materials. They could even be part of the solution to future energy shortages by using plant residues to produce alcohol, thus moving from the petrochemical to the phytochemical era (Duke, 1985). However, many of these species are disappearing due to deforestation and the destruction of ecosystems in the environment. The need to live in harmony with nature is not only derived from moral or ethical convictions, but is based on the most elementary sense of survival.

Their preventive or curative action is due to chemical substances that have a physiological effect on the organism. These substances are known as active ingredients and are generally the product of the secondary metabolism of plants. Active ingredients have medicinal, preventive, health-enhancing and wellness-enhancing properties. Some act as antibiotics or antiseptics, others are sedatives or analgesics, they work as stimulants on the nervous system, or have neuromuscular or muscular activity, among other effects. The study of substances of natural origin that have medicinal properties is known as pharmacognosy, and the effect these substances have on the organism is studied in pharmacology. 
Phytochemistry makes it possible to detect and subsequently identify the active principles responsible for the properties attributed to plants. Chemists determine the presence or absence of the major groups of active substances, such as alkaloids, glycosides, quinones, etc., and proceed to their chemical isolation and characterisation. They then prepare extracts to test their physiological activity, and from the promising extracts they separate and purify the substances that constitute them (Domínguez 1976). The compounds are identified according to their physical and chemical properties, and their structure and configuration are studied.

Sources of reference on general aspects of phytochemistry include the works of Dominguez (1976) and Valencia (1995). The large-scale development of synthetic products, with characteristics similar to those of nature, was reflected in the decline in the use of herbal medicine for some decades. However, with the resurgence of various diseases, increasing incidence of cancer and the emergence of AIDS, the search for new substances was considered urgent (Huerta 1997).

Although the development - up to the commercial level - of new drugs from plants is very costly, and so are the programmes for synthesis of new active ingredients, many drugs are and will continue to be developed from plants traditionally used as medicines. Although the digestive properties of papaya have been known for centuries, it was not until the 1980s, when chymopapain was approved by the US Food and Drug Administration (FDA) to cure back problems, that the use of Lobelia pills to control smoking, long used by Native Americans, began: The use of pure active ingredients, isolated from the plant or synthesised, has the advantage of facilitating dosage and administration; however, it is sometimes less effective than the plant or its parts, as the interaction with other components of the plant enhances the therapeutic effects, which mobilises the absorption of the active substance.

It is necessary to emphasise that chemical synthesis has not been a great success for a natural compound, its properties and its behaviour in the human organism (Sarukhán, 1996). That end (Duke 1985). The higuerilla plant is characterised by its hardiness and adaptability to diverse topographical and climatological conditions, it commonly grows in arid regions with sandy soils and is known by the rural population as a weed without economic significance. However, due to the specific characteristics of its oil, it has emerged as a promising crop that generates high quality raw material for various industries worldwide (Franco, 1999).

In recent years, research into oilseeds and especially the higuerilla plant has undergone significant development in countries such as Brazil and Colombia, in which the public and private sectors have taken part, focusing efforts on developing varieties with specific characteristics for some areas, with better agronomic yields, offering the market certified seed, which guarantees production and product quality, as well as other possibilities of linking its cultivation with other production systems. Potential use of higuerilla by-products in animal feed. Uses of the leaves and stems. The leaves and stems of the higuerilla plant, although not suitable for consumption due to their toxic content of ricin and ricin, have a wide variety of uses, from the manufacture of paper or papyrus for handicraft purposes in Mexico (Escoto García, 2010). In addition to plants, they are essential for life by producing oxygen, regulating the water cycle and being the basis of food chains, nutrients, vitamins and industrial raw materials.

\subsection{Description of the method}

In this work, a series of actions were undertaken in a cross-sectional and longitudinal study. In addition, a quantitative and qualitative analysis was carried out. To this end, seven groups of animals were subjected to experimentation; in this case, wistar spraley rats plus a control, giving a total of eight groups. Each of the groups consisted of four rats placed in a cage, which were numbered from 1 to 4 . All the rats were male, with an average weight of 160 to $200 \mathrm{~g} / \mathrm{kg}$, which later reached a weight of $320 \mathrm{~g} / \mathrm{kg}$ during the time of the experiment. They were administered orally for two months with three types of toxic substances: higuerilla, gigante and caper flower, in order to determine their effect on organs such as the stomach, kidney and liver.

The extracts of these plants were used, all in $500 \mathrm{ml}$ of water. This was done in the following way: 
Figure 10.1 Plant and dose administered by Group

\begin{tabular}{|l|l|}
\hline Group & Plant and dose administered per group \\
\hline Group 1 & Caper flower $10 \mathrm{ml}$ \\
\hline Group 2 & Caper flower $15 \mathrm{ml}$ \\
\hline Group 3 & Higuerilla $10 \mathrm{ml}$ \\
\hline Group 4 & Giant $10 \mathrm{ml}$ \\
\hline Group 5 & Caper Flower $10 \mathrm{ml}$ \\
\hline Group 6 & Caper flower $20 \mathrm{ml}$ \\
\hline Group 7 & Caper flower $30 \mathrm{ml}$ \\
\hline
\end{tabular}

Source: Own research

First, the initial weight of the animals was recorded before the substances of interest were administered to each of the experimental groups, including the control group. After that, a dose containing the substance of interest was given orally to each of the groups and they were weighed again every week. After two months ( 8 weeks), the animals were sacrificed. An analysis was then made to see the variation in the weight of each of the above-mentioned organs as a function of the dose for each of the exposed animals, before and after the toxic substances were administered.

In this way, during the eight weeks, the effect of toxic herbs such as higuerilla, gigante and caperflower on the organs of these species was studied. They were also visualised daily in order to keep a record of their weight as well as their weight loss, depletion, clinical signs and symptoms of toxicity.

\subsection{Analysis from demand curve regression}

\subsection{Results}

During the eight weeks of experimentation, there was an increase in weights. Depressed weights were observed due to toxic effects of giant, figwort and caperflower.

In this context in acute toxicity studies, the mean dose is referred to as the mean lethal dose or LD50, it is important to mention that the mean lethal dose is a statistical dose, not an actual dose. It is derived from the acute toxicity studies mentioned above, where half of the test animals die and half survive.

When reporting the LD50, both the species of the test animals and the route of exposure should be noted, because both are determining factors in determining the LD50. For example, the LD50 for the giant in rats exposed by the route of oral ingestion is reported as follows: LD50 oral, rat. It is very important to mention that separate toxicity tests should be performed for each of the 4 routes of exposure, for which human exposure to chemical agents is expected: ingestion, inhalation, and/or dermal absorption (Penningroth, 2010). A chronic toxicity test in small mammals can cover the entire lifespan of the adult of the test species, two years in mice and two and a half years in rats. Carcinogenicity tests of a chemical agent (potential carcinogen) are chronic toxicity tests, designed for the entire adult life of the test animals. The above exposures manifest themselves in a wide variety of ways, including certain diseases such as cancer, peptic ulcers and reproductive effects, to name but a few. In addition, xenobiotics can have diverse effects at different doses (Smarth and Hodgson, 2008). Subchronic toxicity, as opposed to exposure time in acute toxicity testing, involves repeated doses of the chemical being tested, usually administered over a period of approximately 60 days.

Likewise, when a foreign substance enters the organism, biotransformation plays an important role in reducing or increasing possible toxic effects, so that, just as harmful substances are deactivated, or deprived of their harmfulness, less toxic compounds can be transformed into harmful ones, which are then eliminated after a detoxifying process (Repetto, 2009). The activity of the different metabolic pathways determines the effective concentration of the active metabolism. The use of the leaves and stems of the higuerilla plant, although not suitable for consumption due to its toxic ricinine content, has a wide variety of uses such as the manufacture of handmade paper or papyrus, and the feeding of worms produced in Mexico (Escoto García.2010). Gigante, other common names guayacán, palo blanco, tabaco cimarrón, tabacón, virginio Name: the giant plant. 
Other common names guayacán, palo blanco, tabaco cimarrón, tabacón, virginio. Scientific name: Nicotiana glauca Graham Family: SOLANACEAE low-branching shrub growing up to $6 \mathrm{~m}$ tall, with grey-green or bluish-green stem and foliage, yellow flowers, with more or less cylindrical calyx and corolla.

As the data obtained were analysed, it would be expected that, by providing the same substance in an experimental group, the increase or decrease in the weight of each of the internal organs would be in a similar proportion, however, there was variability in the results. We know that each organism is different and will react differently to the supply of these substances.

The data obtained are shown below. We will start with a comparison of the weights of the different study groups.

Graphic 10.1 Initial weight of the working groups

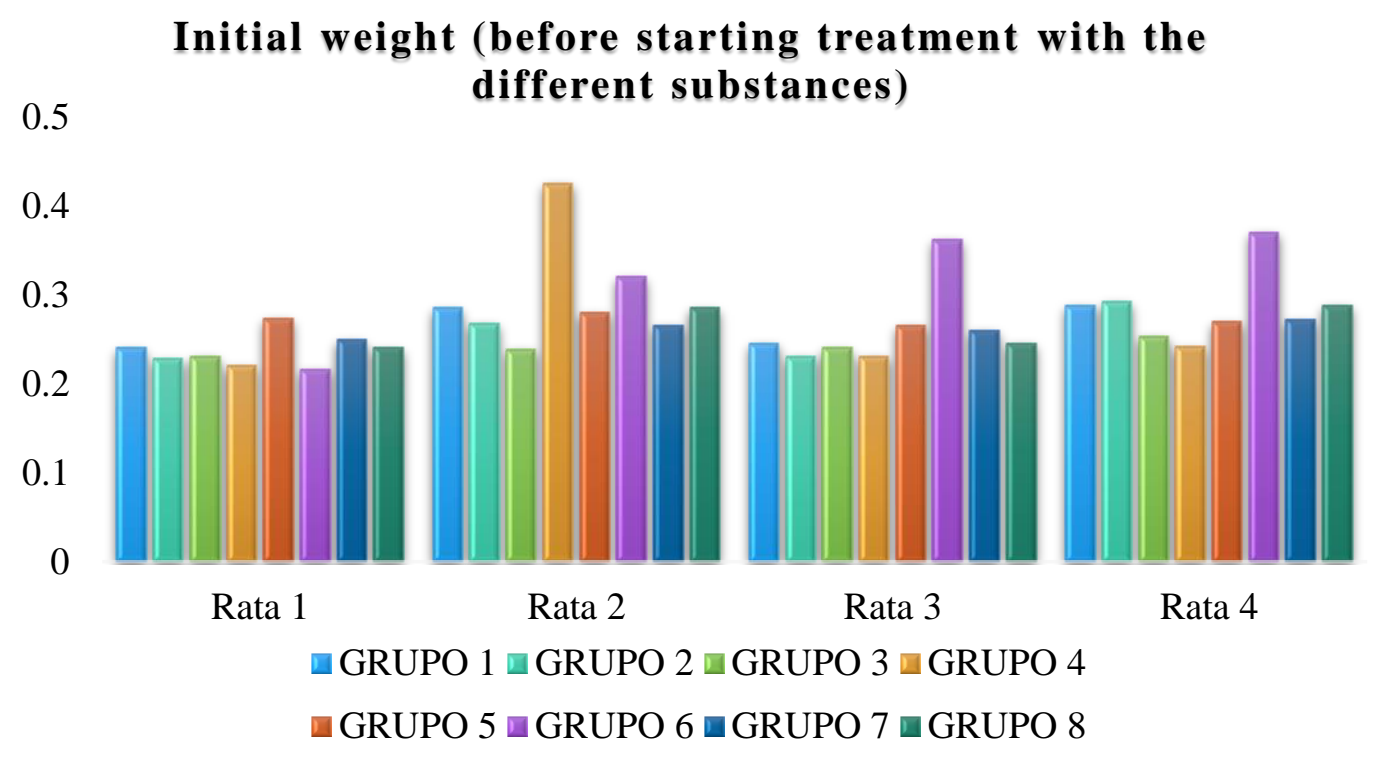

Source: Own research

This analysis, before starting treatment with the different substances, shows that the weights of the rats vary slightly, with the exception of group 6 , where three of them have a higher weight than the rest. In group 4, one of them. The most frequently repeated value is $0.240 \mathrm{~kg} / \mathrm{weight}$.

However, if we look at graphic 10.2, which shows the final weight, the variations found are in groups 6 and 7, where the weight increased when caper flower was given in doses of 20 and $30 \mathrm{ml}$. However, the value that is most frequently found in the sample is $0.246 \mathrm{~kg} / \mathrm{weight}$, so its modification was not significant, except for the cases mentioned above. 
Graphic 10.2 Final weight of the working groups

\section{FINAL WEIGHT (AFTER SUPPLYING THE SUBSTANCE)}

0.5

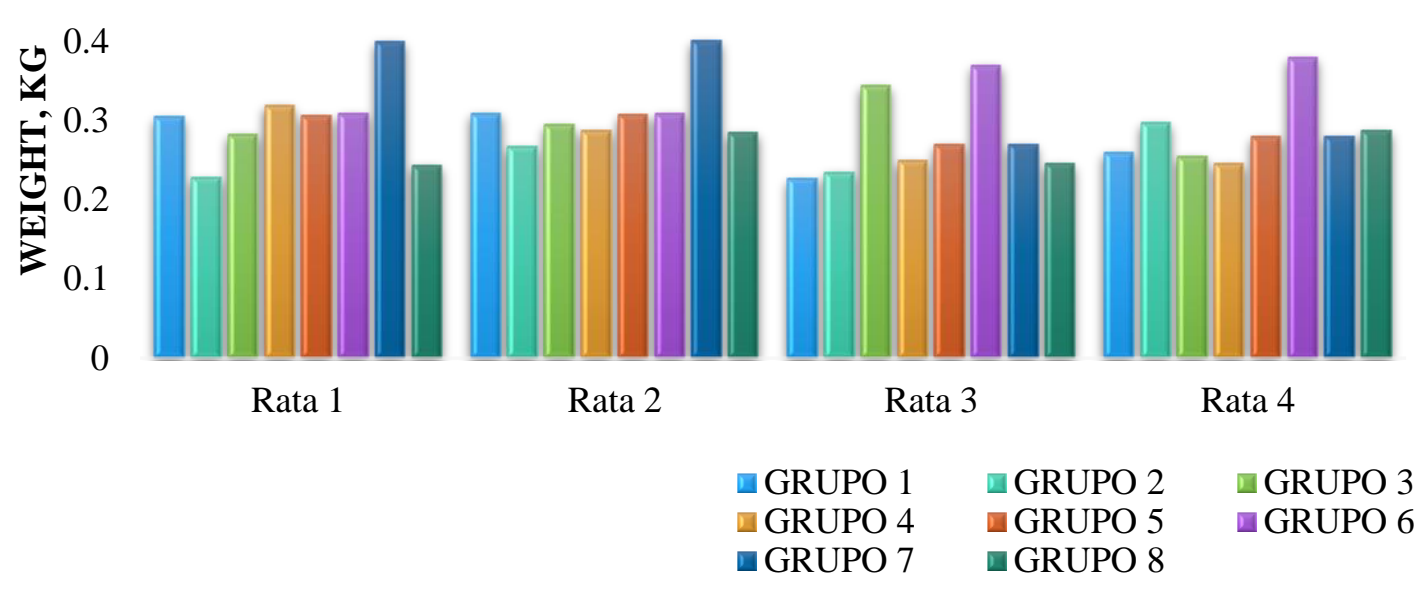

Source: Own research.

It is important to mention that group 8 as a control is only supplied with distilled water and in the graph below we compare group 1 (caper flower, $10 \mathrm{ml}$ ) and group 8 in order to observe the changes in weight after the time of experimentation in the supply of the substances. In the latter group the possible variations in weight are almost imperceptible, of a few decimal places. Therefore, a constant weight is maintained.

Graphic 10.3 Comparison of the initial weight between groups 1 and 8

\section{GROUP 1 Vs GROUP 8}

$$
0.35
$$
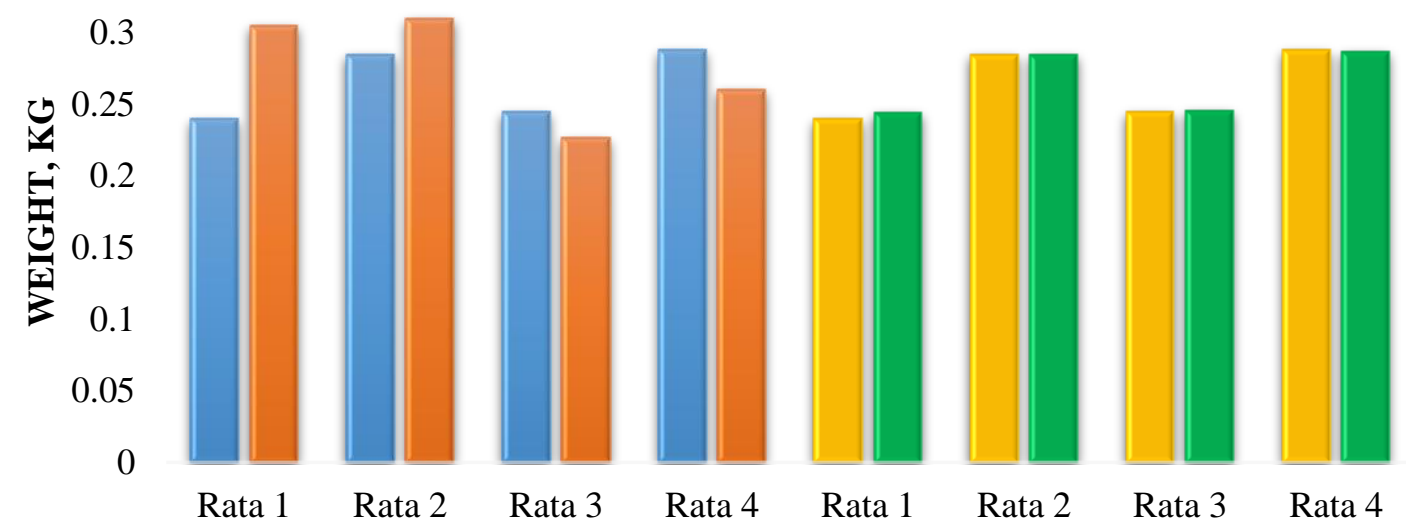

口Peso inicial $\square$ Peso después de 2 meses

Source: Own research

Liver

When examining the results concerning liver weight, in group 1 and 2 where caper flower was administered in doses of 10 and $15 \mathrm{ml}$ respectively, the liver had a considerable decrease in weight. This could be attributed to their heterogeneity and the effect of the doses on the species, environmental factors, differences in the organisms, as well as the effects of the toxicity of the active ingredients in each of the rats. Some toxicants cause symptoms within seconds, while others cause symptoms only after several hours, days or even years. Others do so by causing obvious symptoms before they have caused damage to vital organs, such as the kidneys or liver, sometimes permanently. 
Graphic 10.4 Liver analysis, group 1

\section{GROUP 1, LIVER ANALYSIS}

$$
0.35
$$
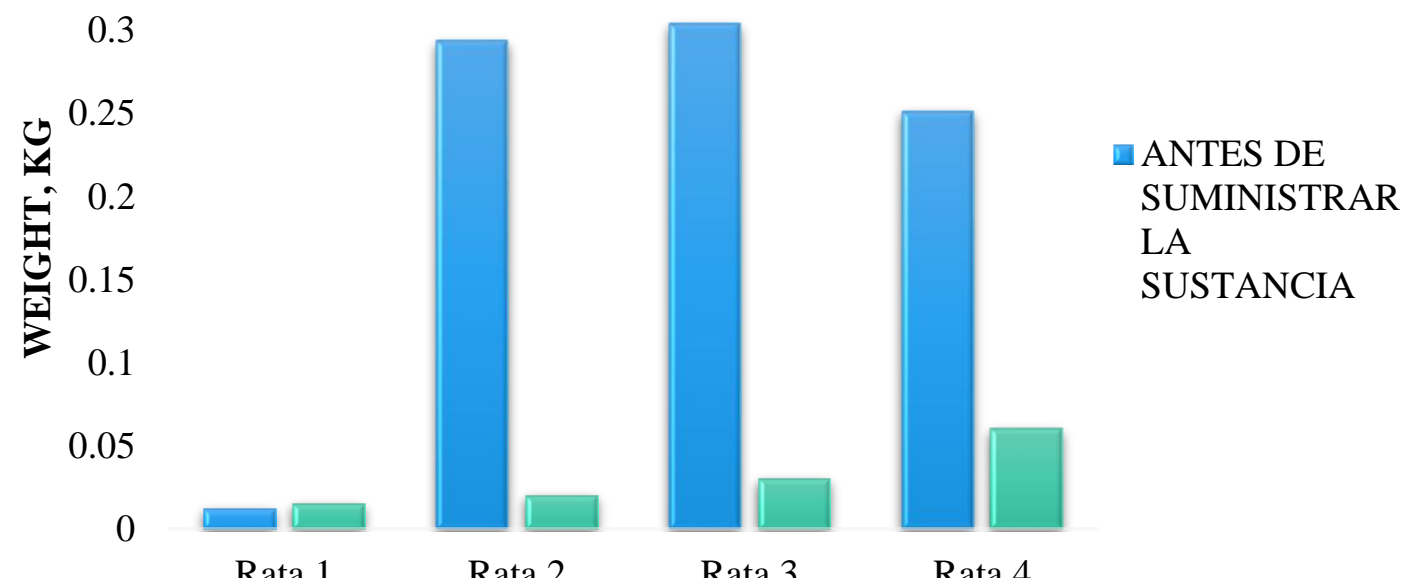

Rata 1

Rata 2

Rata 3

Rata 4

Source: Own research

Graphic 10.5 Liver analysis, group 2

\section{GROUP 2. LIVER ANALYSIS}

0.3

0.2

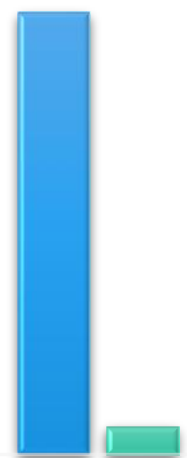

Rata 3

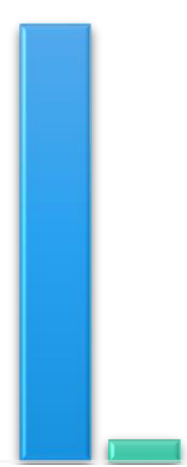

Rata 4
- ANTES DE SUMINISTRAR

LA SUSTANCIA

口 DESPUÉS DE SUMINISTRAR

LA SUSTANCIA

Source: Own research.

For group 3 the substance supplied was $10 \mathrm{ml}$ of higuerilla and in this group the liver weight was not affected to a great extent, but in group 4 where the giant was used, the weight of the liver increased notoriously. 
Graphic 10.6 Liver analysis, group 3

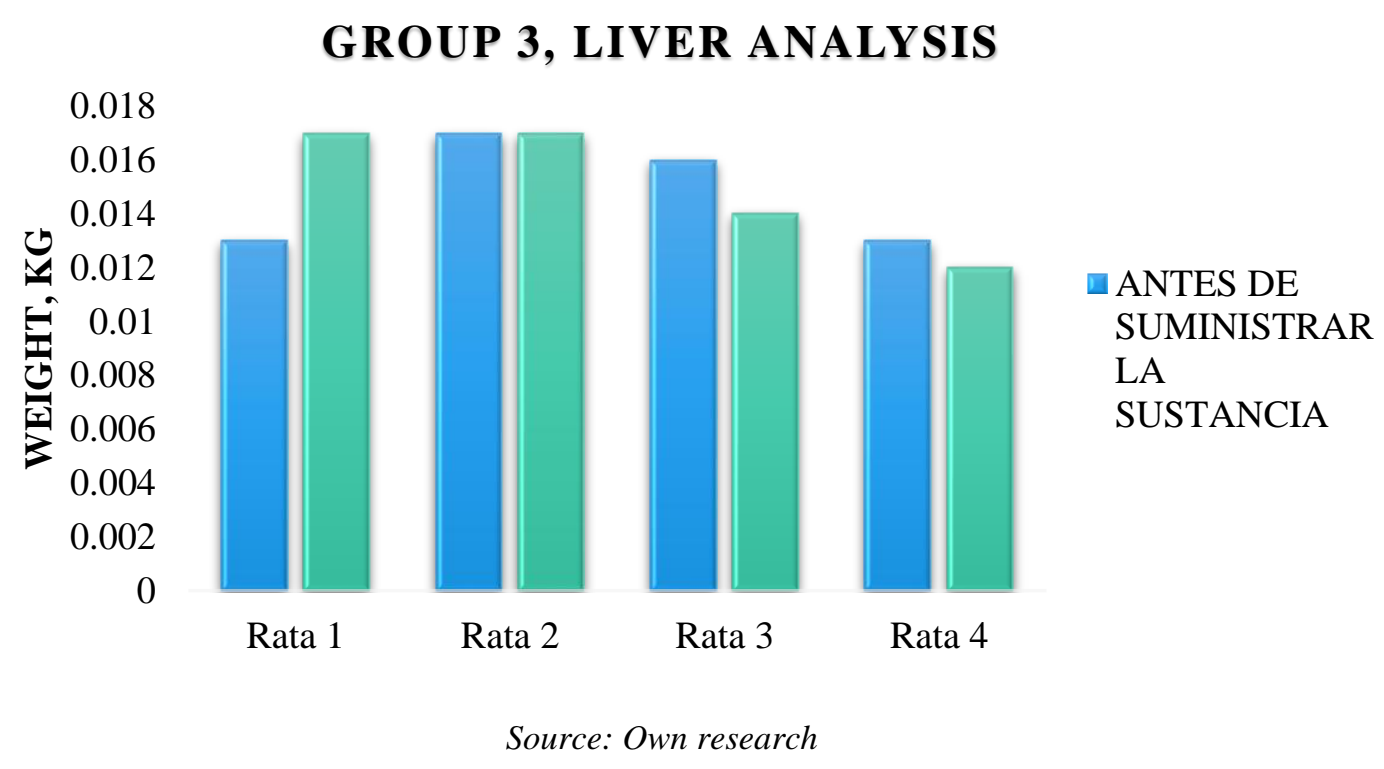

Graphic 10.7 Liver analysis, group 4

\section{GROUP 4, LIVER ANALYSIS}

0.025

0.02
0.015
0.005

0

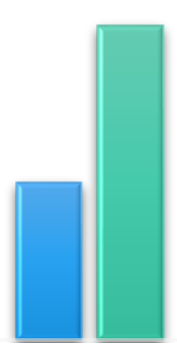

Rata 1

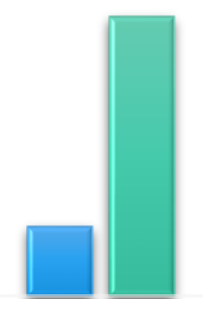

Rata 2

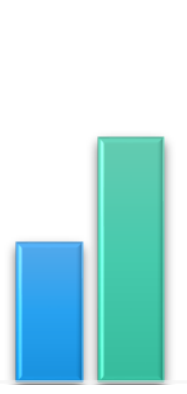

Rata 3

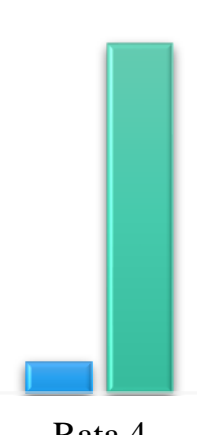

Rata 4
- ANTES DE

SUMINISTRAR LA

SUSTANCIA

口 DESPUÉS DE

SUMINISTRAR LA

SUSTANCIA

Source: Own research.

In group 5 again $10 \mathrm{ml}$ of caper flower was used. It is observed that there is a considerable decrease in two of their species after administering the substance.

Graphic 10.8 Liver analysis, group 5

\section{GROUP 5, LIVER ANALYSIS}

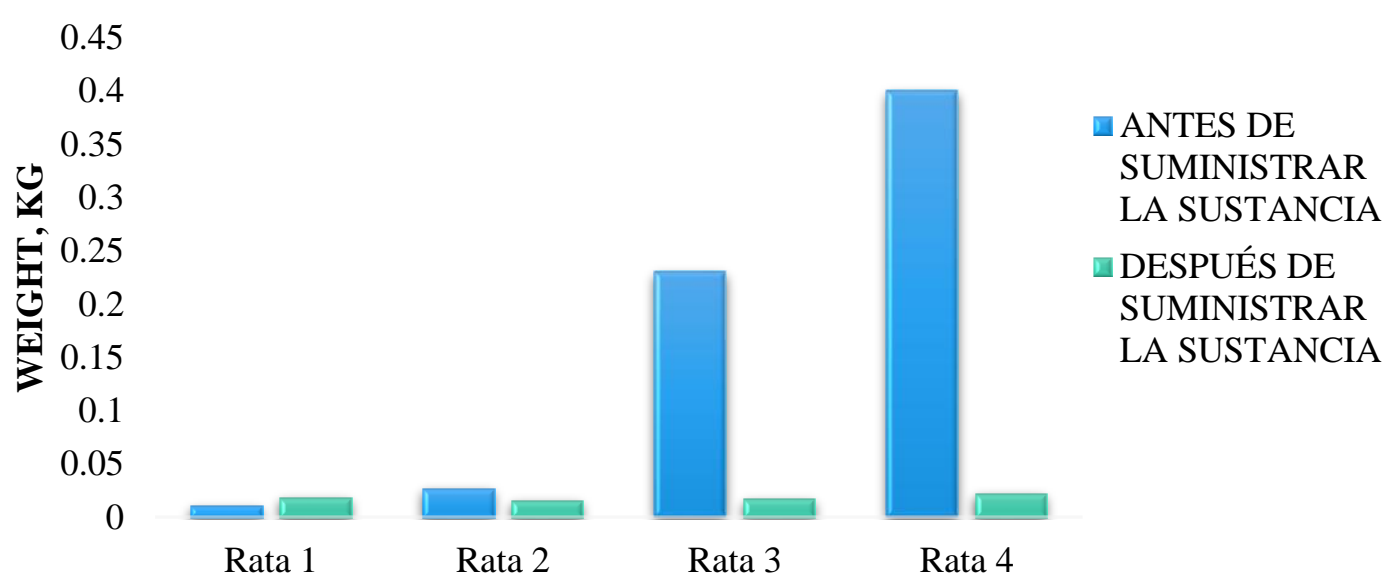

Source: Own research 
For group 6 (20 ml caper flower) the weight is higher in three of the species, with number 2 showing a considerably different weight before and after the supply of the substance. While in number 1 there is no considerable change.

Graphic 10.9 Liver analysis, group 6

\section{GROUP 6, LIVER ANALYSIS}

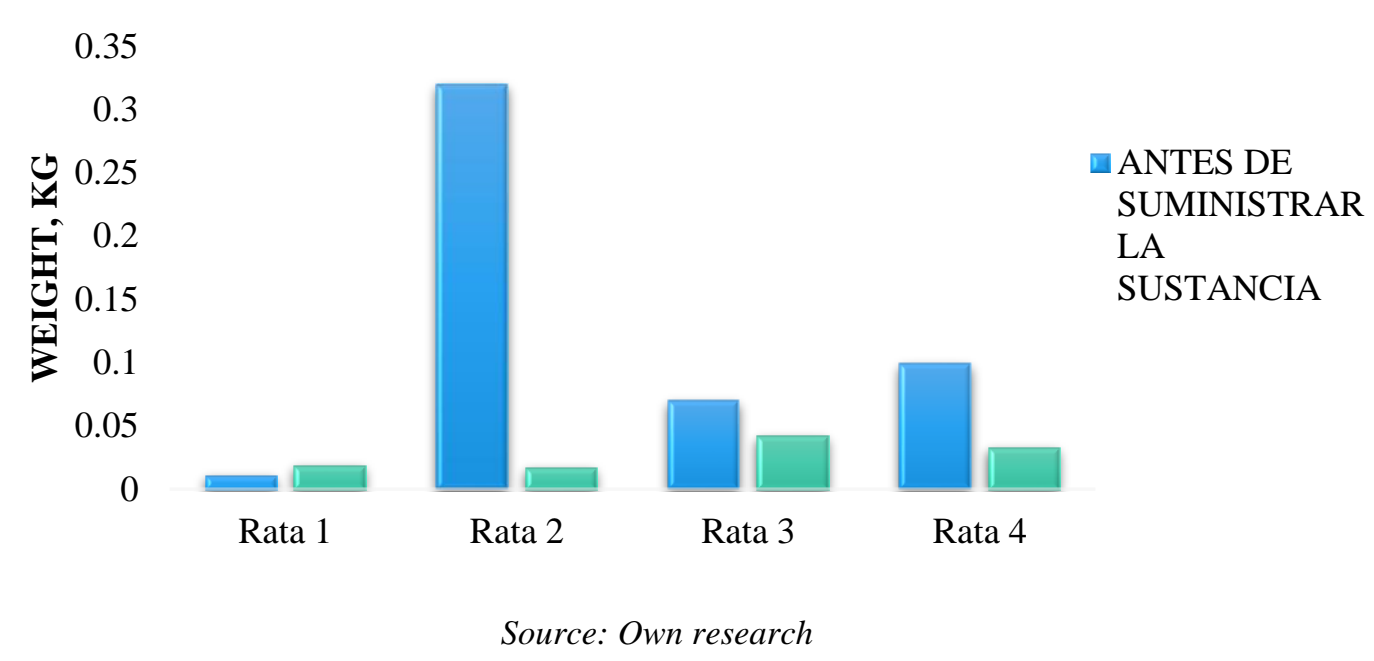

As for group 7 ( $30 \mathrm{ml}$ caper flower), also in this group the species marked as number 2 shows a significant difference, as the weight of its liver decreased considerably, unlike the other 3 , where it was very similar.

Graphic 10.10 Liver analysis, group 7

\section{GROUP 7, LIVER ANALYSIS}

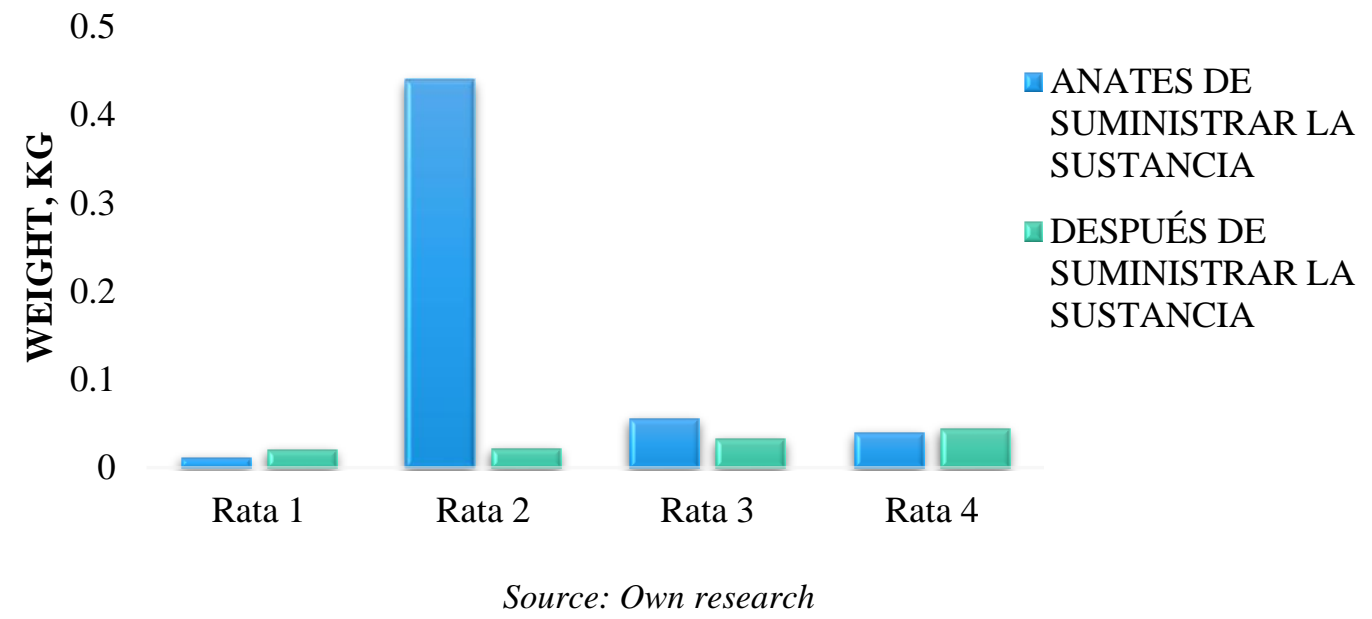

This was not the case in group 8, which was supplied with distilled water. Here three of the rats decreased their weight considerably while one increased it by 5 percentage units. A surprising aspect of metabolism is that the system itself alters the chemicals to allow their efficient elimination from the body. 
Graphic 10.11 Liver analysis, group 8

\section{GROUP 8, LIVER ANALYSIS}

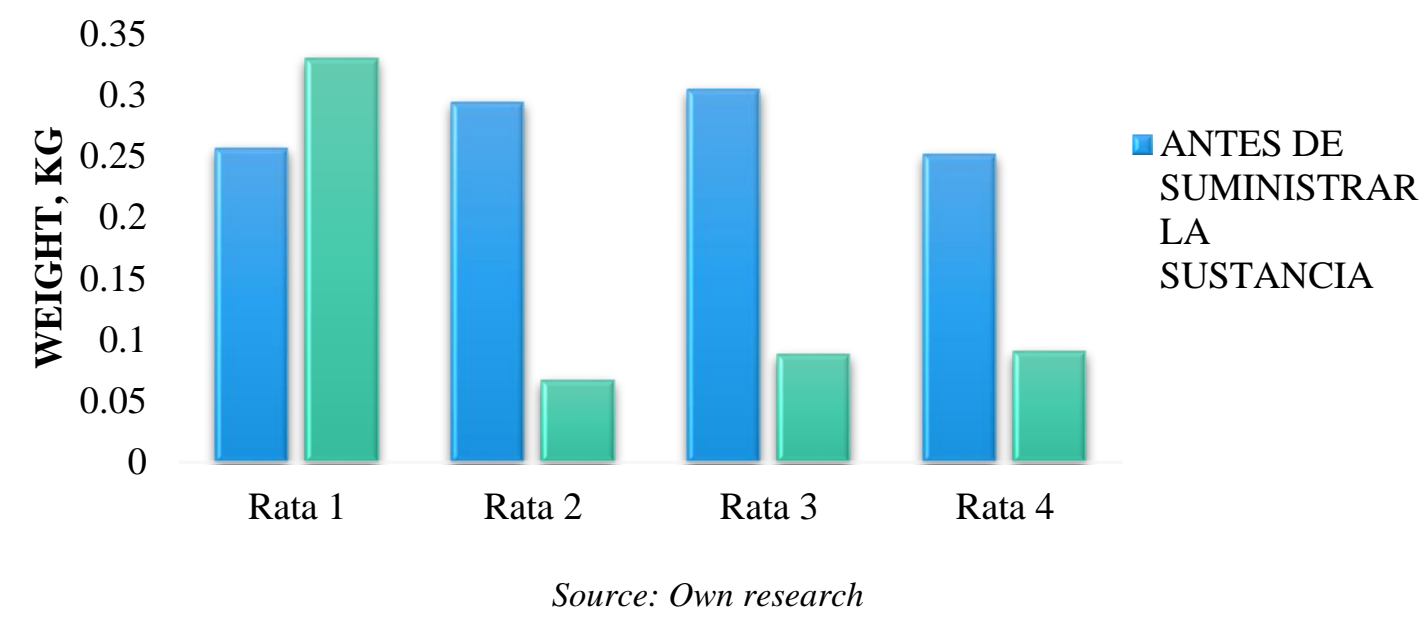

\section{Kidney}

Free radical formation increases as a consequence of the toxicity of a wide range of xenobiotics. A large number of chemical compounds, in order to exert their toxic action, require metabolic activation to reactive intermediates that can generate free radicals (Plant, 2003). Caustic or irritant substances injure the mucous membranes of the mouth, throat, gastrointestinal tract and lungs, causing pain, coughing, vomiting and shortness of breath. When observing the results obtained in the kidney, again when caper flower was administered (group 1 and 5 with $10 \mathrm{ml}$ ) one or two rats increased in size, likewise in group 2 with $15 \mathrm{ml}$ of caper flower the same tendency was observed. The rest of the species in these groups do not.

Graphic 10.12 Kidney analysis, group 1

\section{GROUP 1, KIDNEY ANALYSIS}

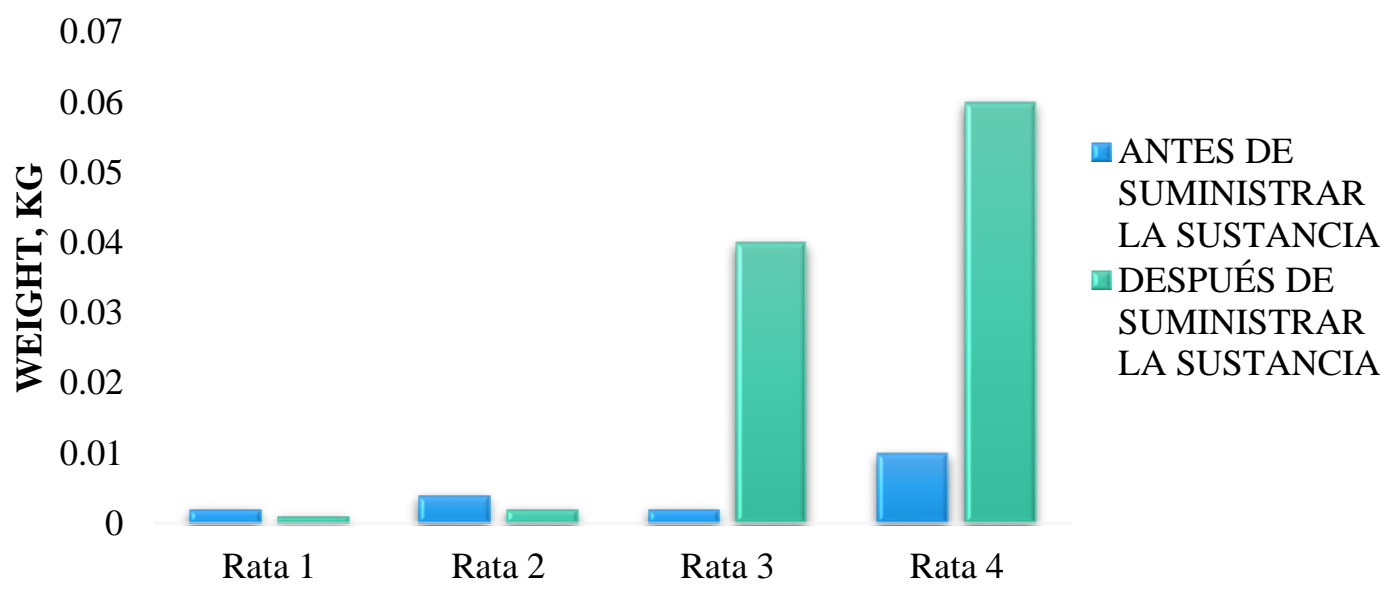

Source: Own research 
Graphic 10.13 Kidney analysis, group 2

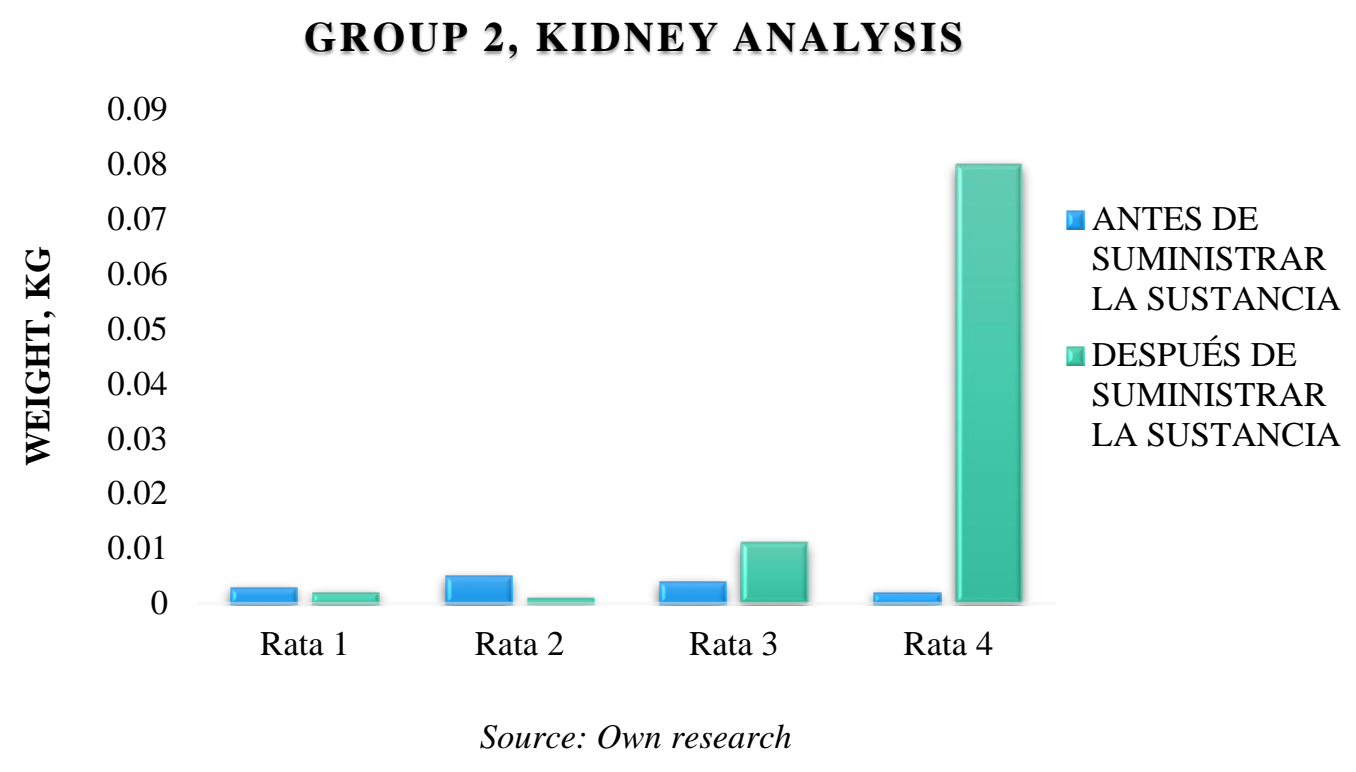

For group 3, a decrease is observed when treated with higuerilla, while in the group that was supplied with giant fig (group 4), a slight increase is observed in 3 of the species.

Graphic 10.14 Kidney analysis, group 3

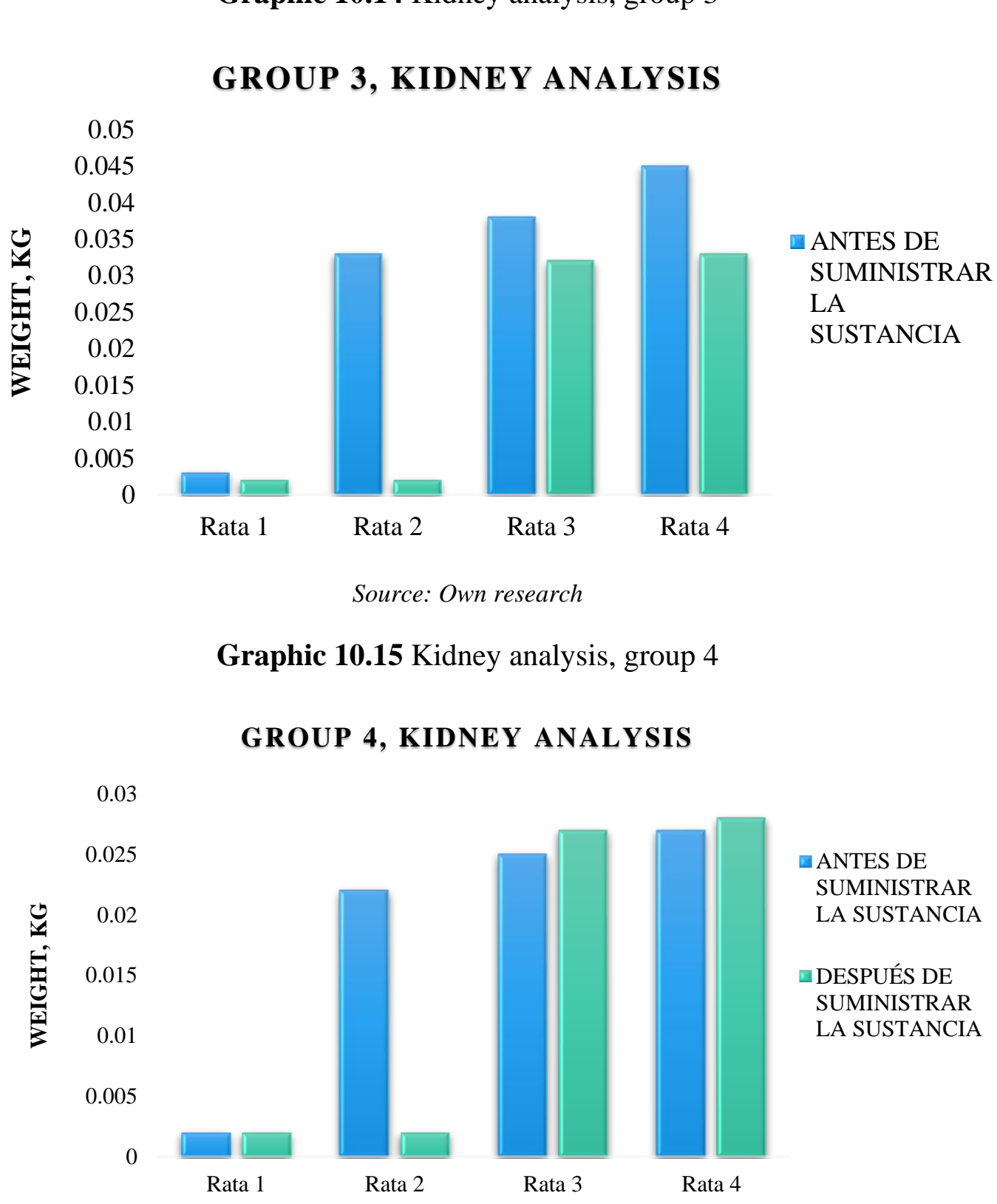

Source: Own research 
In groups 6 and 7, on the other hand, the decrease is notorious.

Graphic 10.16 Kidney analysis, group 5

\section{GROUP 5, KIDNEY ANALYSIS}

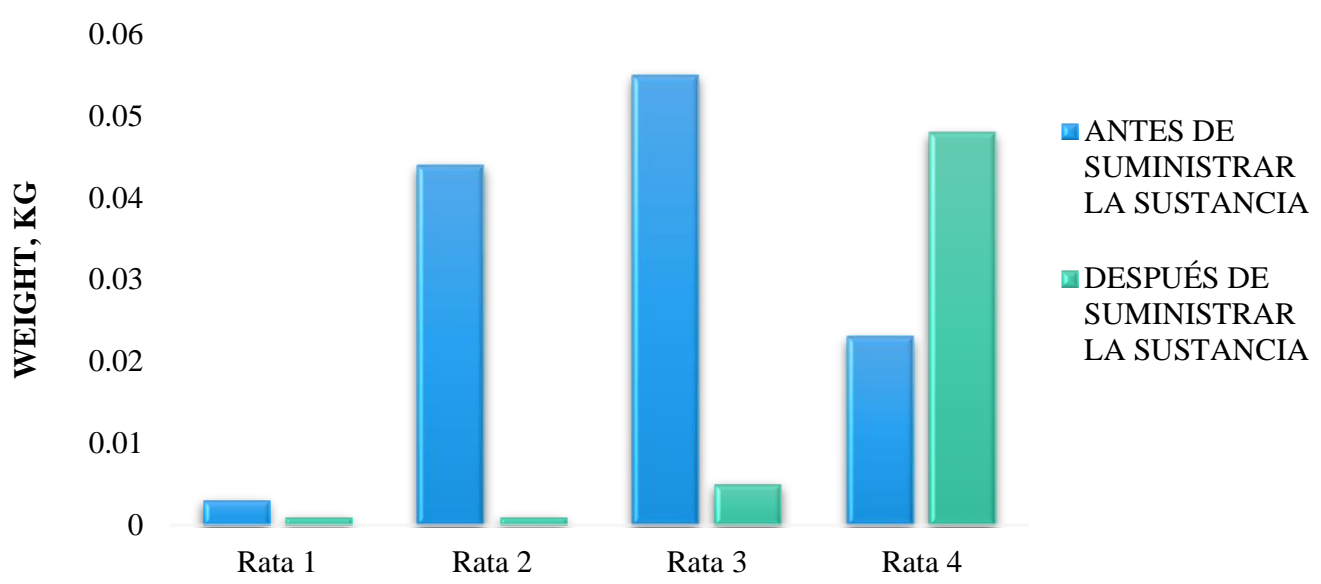

Source: Own research

Graphic 10.17 Kidney analysis, group 6

\section{GROUP 6, KIDNEY ANALYSIS}
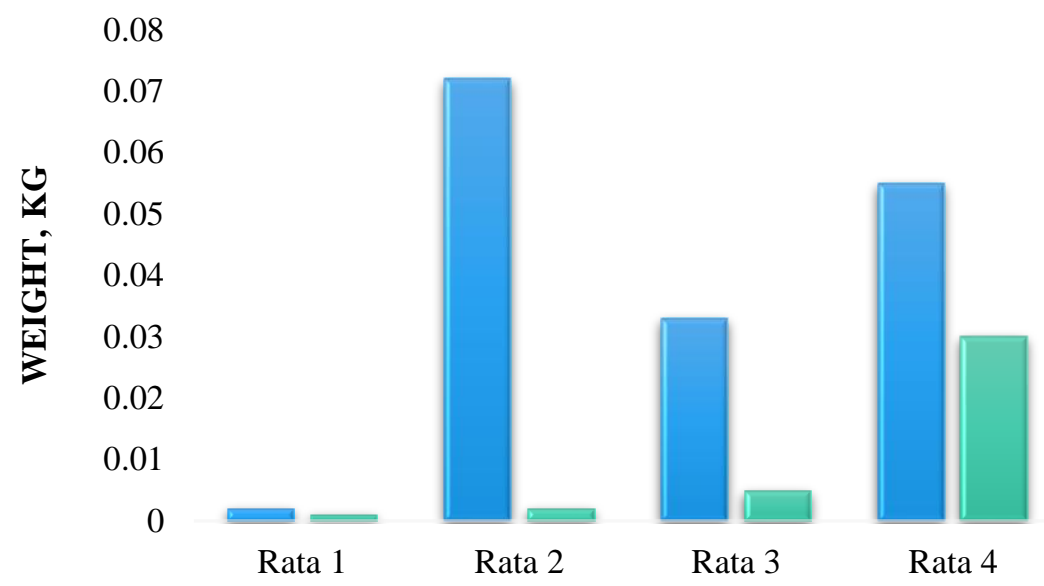

- ANTES DE

SUMINISTRAR

LA SUSTANCIA

- DESPUÉS DE

SUMINISTRAR

LA SUSTANCIA

Source: Own research

Graphic 10.18 Kidney analysis, group 7

\section{GROUP 7, KIDNEY ANALYSIS}
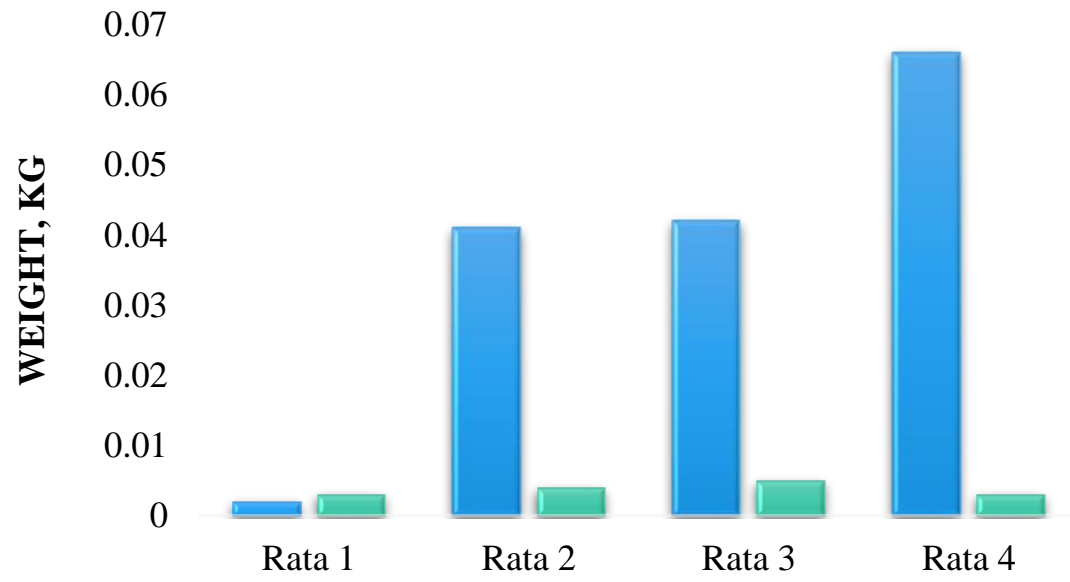
$\square$ ANTES DE
SUMINISTRA
R LA
SUSTANCIA
SUMINISTRA
R LA
SUSTANCIA

\section{Rata 3}

Rata 4

Source: Own research 
Graphic 10.19 Kidney analysis, group 8

\section{GROUP 8, KIDNEY ANALYSIS}

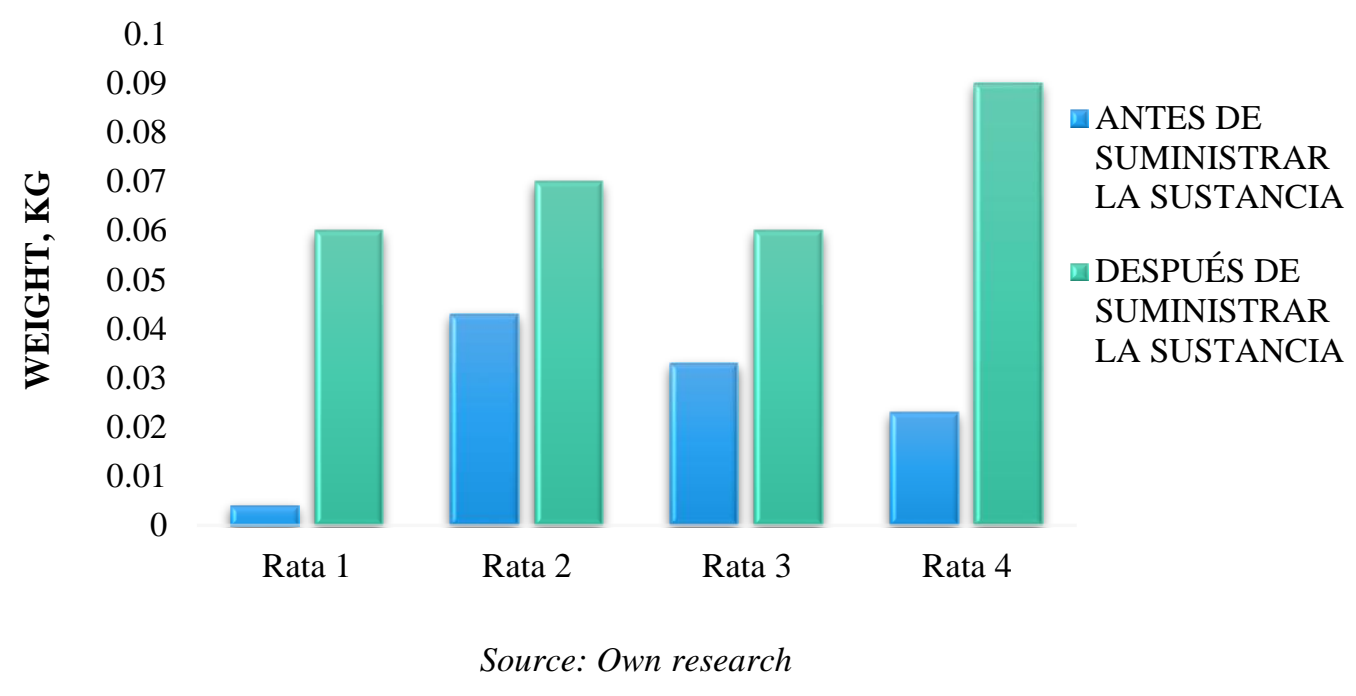

However, for the group treated with distilled water alone (group 8) the kidney size increased considerably.

\section{Stomach}

A striking aspect of metabolism is that the system itself alters chemicals to allow their efficient elimination from the body, it can also produce numerous chemical species that may be toxic to the cell (bioactivation). These species can be divided into two general categories, reactive intermediates formed from the metabolism of a chemical agent (e.g., large chemical structures with reactive groups) and small chemically reactive species released during metabolism (e.g., small mono- or diatomic species) (Smart and Hodgson).

When the different working substances were tested, the effects on the stomach were as follows:

In groups 1, 2, 5, 6 and 7, although caper flower was administered in all cases, only groups 1, 2 and 6 showed increases in the weight of the caper flower. For the block corresponding to group 5, the increase was not so pronounced. However, in group 7 there was a decrease in only two species, while in the remaining ones the weight remained constant.

Graphic 10.20 Stomach analysis, group 1

\section{GROUP 1, STOMACH ANALYSIS}

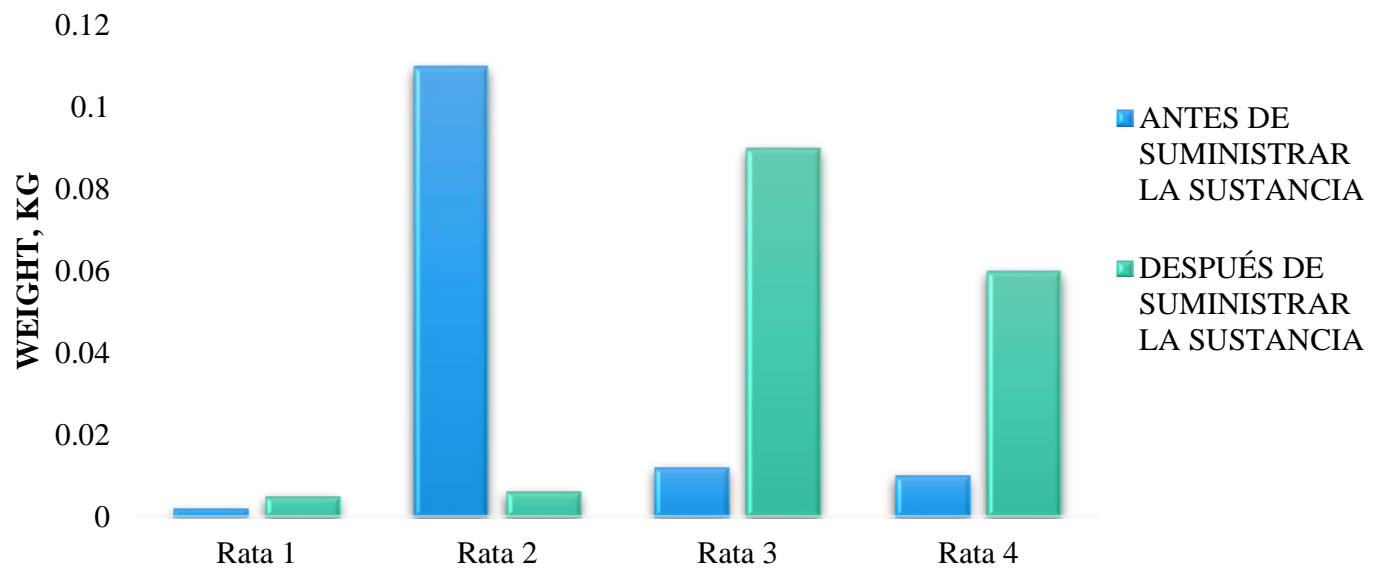

Source: Own research 
Graphic 10.21 Stomach analysis, group 2

GROUP 2, STOMACH ANALYSIS

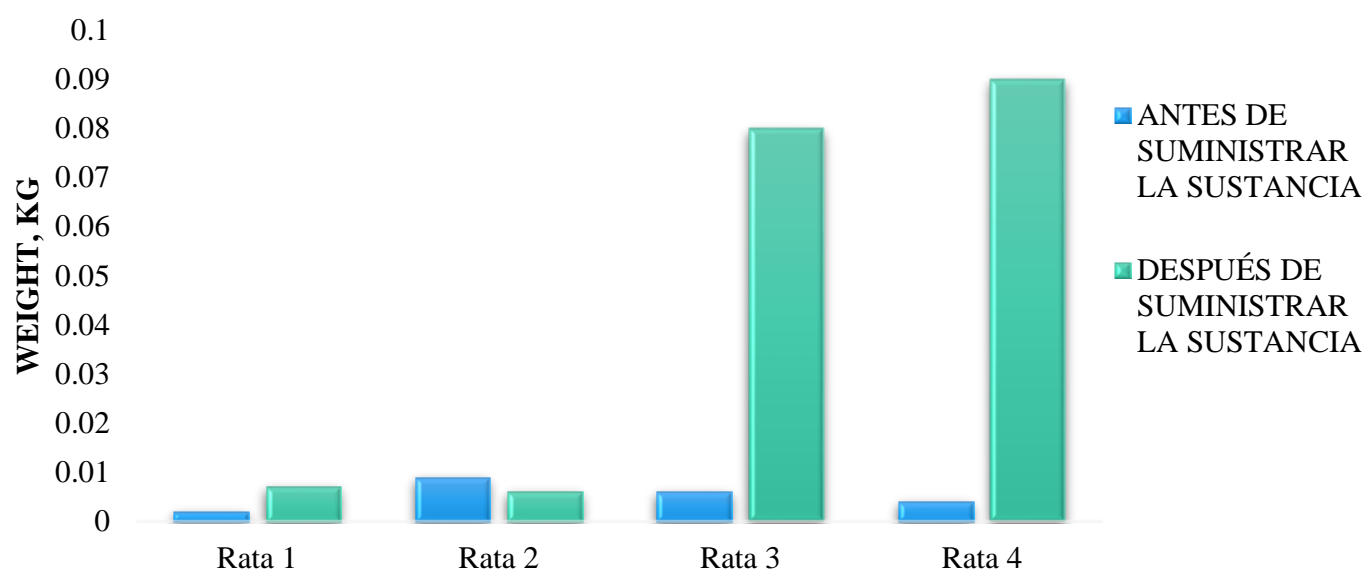

Source: Own research

Graphic 10.22 Stomach analysis, group 3

\section{GROUP 3, STOMACH ANALYSIS}

0.08

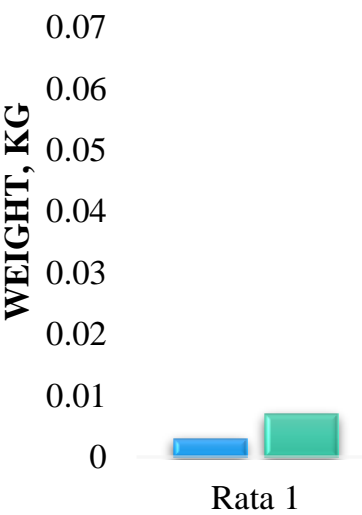

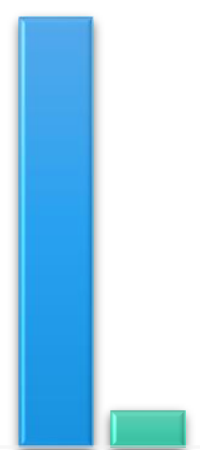

Rata 2

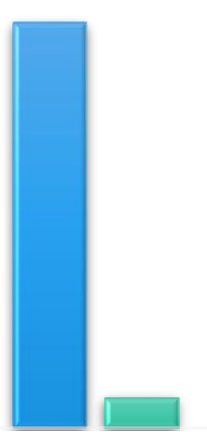

Rata 3

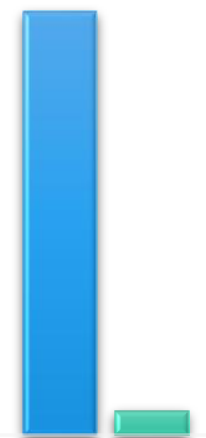

Rata 4
口 ANTES DE

SUMINISTRAR

LA SUSTANCIA

DESPUÉS DE

SUMINISTRAR

LA SUSTANCIA

Source: Own research

Graphic 10.23 Stomach analysis, group 4

\section{GROUP 4, STOMACH ANALYSIS}

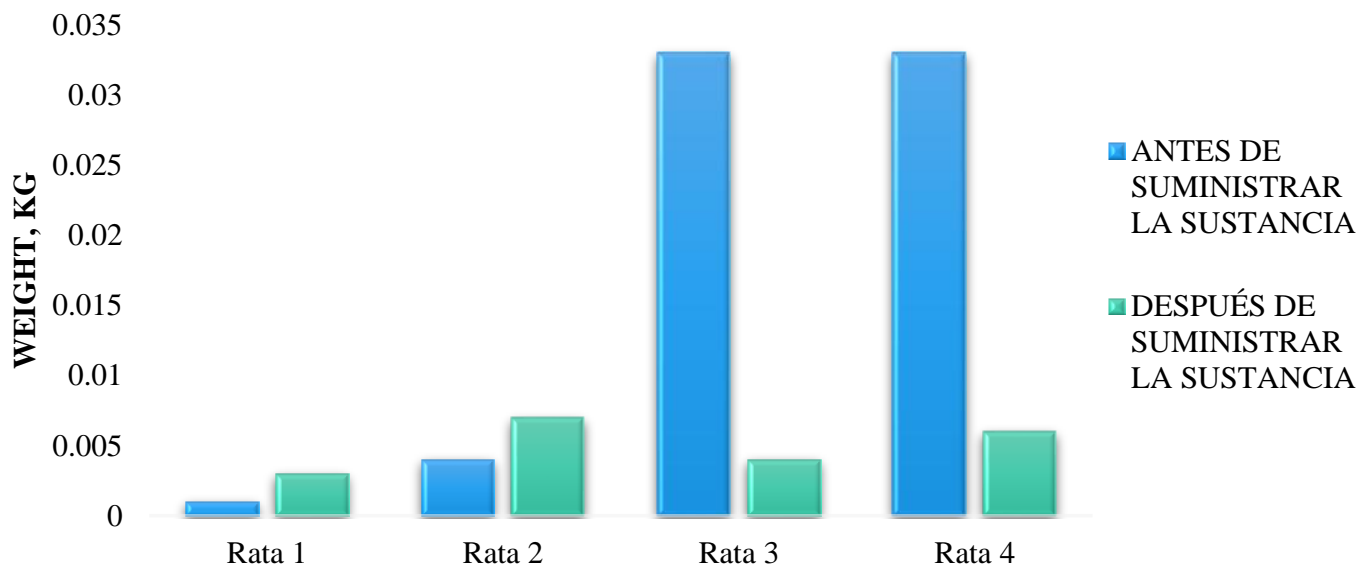

Source: Own research

In the case of groups 3 and 4, the decrease is very noticeable. 
Graphic 10.24 Stomach analysis, group 5

\section{GROUP 5, STOMACH ANALYSIS}

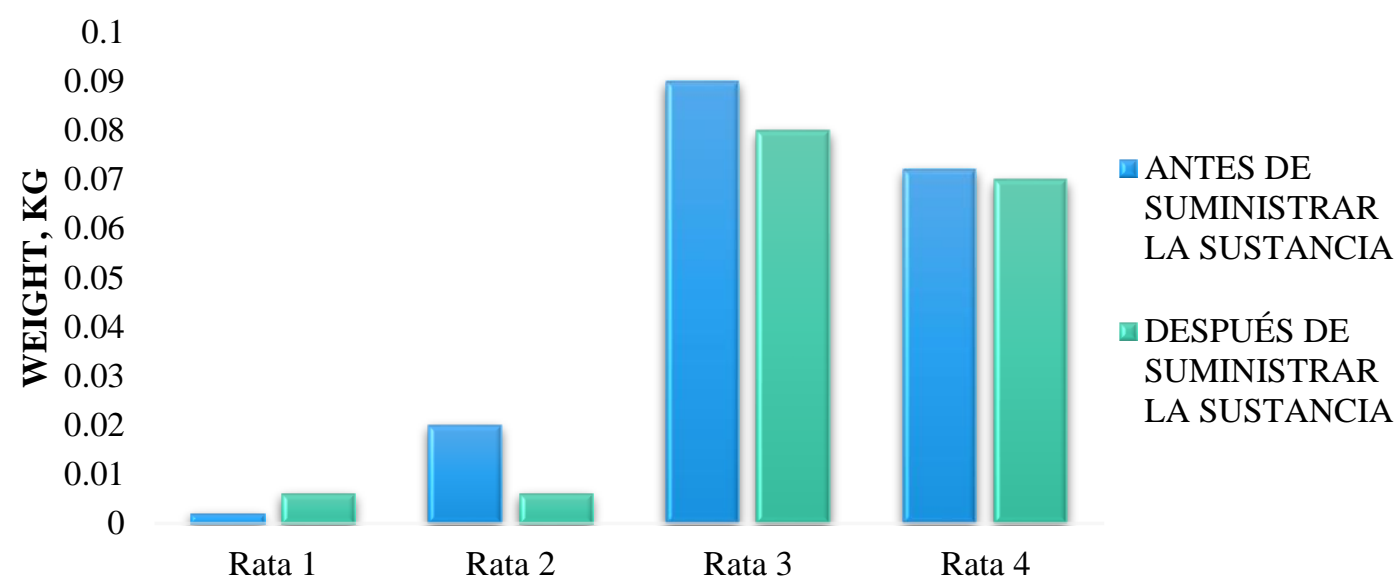

Source: Own research

Graphic 10.25 Stomach analysis, group 6

\section{GROUP 6, STOMACH ANALYSIS}

0.12

0.1

0.08
0.06
0.006

0.02

0

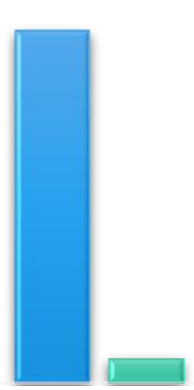

Rata 2

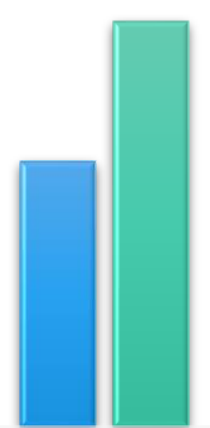

Rata 3

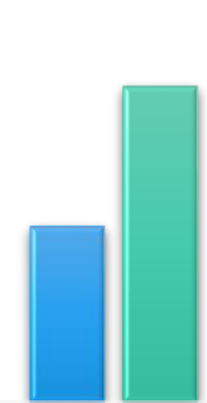

Rata 4
ANTES DE

SUMINISTRAR

LA SUSTANCIA

■DESPUÉS DE

SUMINISTRAR

LA SUSTANCIA

Source: Own research

Graphic 10.26 Stomach analysis, group 7

\section{GROUP 7, STOMACH ANALYSIS}

0.6

0.5

0.4
0.3
0.0 .3

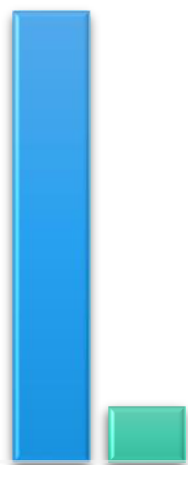

Rata 3
ANTES DE

SUMINISTRAR

LA SUSTANCIA

匹 DESPUÉS DE

SUMINISTRAR

LA SUSTANCIA

0.1

Rata 1
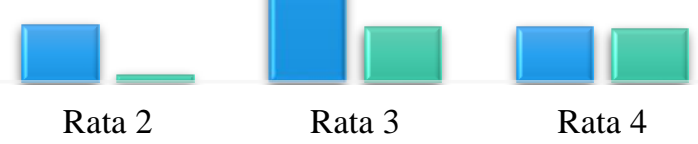

Rata 4

Source: Own research 
Graphic 10.27 Stomach analysis, group 8

\section{GROUP 8, STOMACH ANALYSIS}

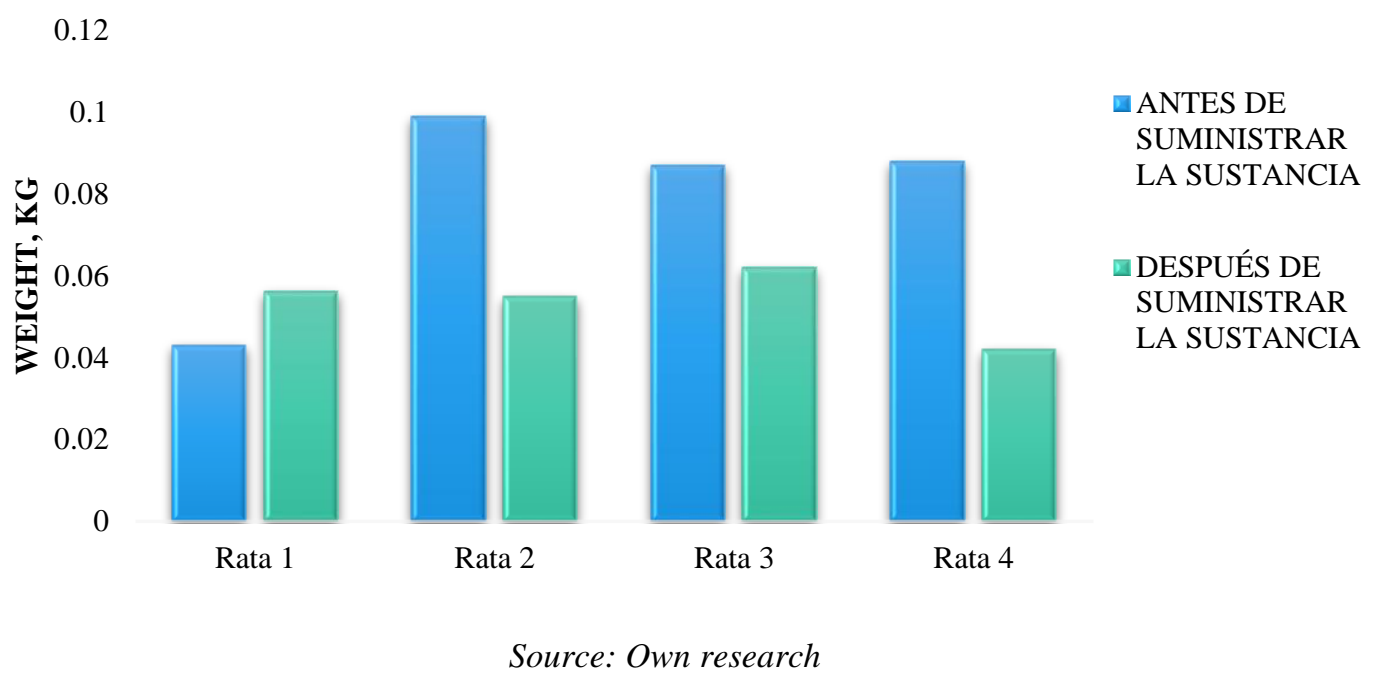

For the species in the distilled water supply group, the size of the distilled water decreases to almost half of its normal size in 3 of the rats. In one of them there is a slight increase.

\subsection{Acknowledgements}

To the authors, the anonymous reviewers and the editor for their valuable suggestions to improve the document, as well as the informants of the participation, authorities of the Academic Unit of Chemical Sciences Area of Health Sciences of the Universidad Autónoma Zacatecas.

\subsection{Conclusions}

It is important to mention that when a foreign substance enters the body, biotransformation plays an important role in reducing or increasing possible toxic effects. Particularly in this study, variability in results was observed when different poisonous plants were fed to the same working group. This could be attributed to the difference in organisms and thus the reaction to each toxic substance would also be different, so that the system would be altered, producing some effect on the increase or decrease in the weight of the different organs analysed. It is important to mention that these plants in our case could be harmful to these organisms, however, at some point they could be a promising option for cultivation due to the type of soil and environmental conditions, generating a benefit by being included in the market for use in various economic sectors.

\subsection{References}

Anderssona, E. F; Eversona, T. \& Everson, C. S. (2012). Management of oil producing Jatropha curcas silvopastoral systems: Risk of herbivory by indigenous goats and competition with planted pastures. School of Life Sciences.

El uso de las plantas medicinales en las comunidades maya-chontales de Nacajuca, Tabasco, México. Polibotánica, Magaña AMA. 2012. Etnobotánica de las plantas medicinales en los huertos familiares de Tabasco, En Mariaca R. El huerto familiar del sureste de México. Ed. Secretaría de Recursos Naturales y Protección Ambiental del Estado de Tabasco y El Colegio de la Frontera Sur, México.

Ethnologue: Languages of the World, Nineteenth edition. Dallas, Texas, USA. López A. 1984a. Textos de medicina náhuatl. UNAM, México DF, México. López A. 1984b. Cuerpo humano e ideología. Las concepciones de los antiguos nahuas. Ed. Instituto de Investigaciones Antropológicas, UNAM, México DF, México. López A. 1996. 
La cosmovisión mesoamericana. En Lombardo S, Nalda E. Temas mesoamericanos, INAH/CONACULTA, México, Lot A, Chiang F. 1986. Manual de herbario. Consejo Nacional Flora de México. México DF, México. Lozoya X. 1984. Bibliografía básica sobre herbolaria medicinal en México. Secretaría de desarrollo urbano y ecología, México DF.

La vegetación de la laguna de las ilusiones. Ed. Universidad Juárez Autónoma de Tabasco, Villahermosa, Tabasco, México. Magaña AMA. 1995. Catálogo de nombres vulgares y científicos de plantas de Tabasco. Ed. Universidad Juárez Autónoma de Tabasco, Villahermosa, Tabasco, México. Magaña AMA. 2010. Vegetación y flora del municipio de Paraíso.

Lans CA. 2006. Ethnomedicines used in Trinidad and Tobago for urinary problems and diabetes mellitus. J Ethnobiol Ethnomed 2:45. León H, Vásquez MA. 2003. Plantas útiles de San Juan Cacahuatepec, Costa de Oaxaca, México. Ed. Dirección General de Culturas Populares e Indígenas, México DF, México. Lewis MP, Gary FS, Charles DF. 2016.

Lot A, Chiang F. 1986. Manual de herbario. Consejo Nacional Flora de México. México DF, México. Lozoya X. 1984. Bibliografía básica sobre herbolaria medicinal en México. Secretaría de desarrollo urbano y ecología, México DF.

Luna LM, González AR, de la Cruz I. 2006. Transmisión del conocimiento herbolario entre los zoques de Rayón, Chiapas, En Aramoni D, Lee TA, Lisbona M. Presencia zoque. Una aproximación multidisciplinaria. Ed. Universidad de Ciencias y Artes de Chiapas, México.

Madsen W, 1955. Hot and Cold in the Universe of San Francisco Tecospa, Valley. J Am Folk 68: 123 139. Magaña AMA. 1988.

Manual de agroforesteria. Proyecto manejo sostenible de recursos naturales. ISBN: 978-99953-65-00San Lorenzo, Paraguay. Córdoba, O. J. (2012). Comportamiento eco fisiológico.

University of KwaZulu-Natal. Scottsville, Pietermaritzburg. South África. Cavalcante, F. S. (2004). A Importancia da Mamona para a agricultura familiar no estado da Paraíba. Revista electrónica de ciencias, 27. Chávez, D. (2007). 